Please do not remove this page

RMIT

UNIVERSITY

\title{
Executive valuation of simple compensation packages: Risk aversion, leverage and volatility
}

Heaney, Richard

https://researchrepository.rmit.edu.au/esploro/outputs/9921858322101341/filesAndLinks?institution=61RMIT_INST\&index=null

Heaney, R. (2005). Executive valuation of simple compensation packages: Risk aversion, leverage and volatility. Managerial Finance, 31(7), 91-108. https://doi.org/10.1108/03074350510769767

Published Version: https://doi.org/10.1108/03074350510769767

Repository homepage: https://researchrepository.rmit.edu.au

(C) Barmarick Publications

Downloaded On 2023/04/27 01:29:26 +1000

Please do not remove this page 
Citation:

Heaney, R 2005, 'Executive valuation of simple compensation packages: Risk aversion, leverage and volatility', Managerial Finance, vol. 31, no. 7, pp. 91-108.

\title{
Executive valuation of simple compensation packages The interaction of risk aversion, leverage and volatility
}

\author{
Richard Heaney* \\ Australian National University
}

\begin{abstract}
This paper analyses the value to a poorly diversified risk-averse executive of a compensation package consisting of a risk free asset, restricted stock and stock options. The Lambert, Larcker and Verrecchia (1991) model is extended to include leverage and this facilitates comparison of cost to the firm and benefits to the executive of restricted stock and stock options. It also provides insight into the impact of executive risk aversion, firm leverage and underlying asset volatility on the value of a compensation package in the hands of the executive.
\end{abstract}

JEL Code: G34

Key Words: executive, compensation, stock-options, stock, risk-aversion, leverage, volatility

Accepted for publication in Managerial Finance

* $\quad$ School of Finance and Applied Statistics, Australian National University

Canberra, Australia, Phone 612 61254726, Fax. 612 61250087, Richard.Heaney@anu.edu.au 


\section{Introduction}

The setting of executive compensation is an important responsibility of the board of directors. Although compensation has an impact on executive behaviour and it has also been argued to have an impact on corporate performance. Kole (1997) identifies three broad types of compensation, restricted stock based compensation, stock option based compensation and long-term performance plans. While all three compensation methods are evident in large American corporations (Kole, 1997), this paper focuses on the choice between an investment in risk free assets, restricted stock and stock options in line with Lambert, Larcker and Verrecchia (1991) and Hall and Murphy (2000). To date analysis of management compensation has tended to ignore the impact of leverage though it is apparent that leverage should be important (Cooper and Mello, 1999, Galai and Masulis, 1976, Jensen and Meckling, 1976, John and John, 1993, Garvey 1997, Guay, 1999 and Mehran, 1992). While this paper provides insight into the impact of leverage on the value of a compensation scheme to a poorly diversified risk-averse executive the impact of risk-aversion and underlying asset price volatility are also discussed.

The relation between executive compensation and firm performance has generated considerable research (Core, Holthausen and Larcker, 1999, Campbell and Wasley, 1999, Demsetz and Villalonga, 2001, Himmelberg, Hubbard and Palia, 1999, Loderer and Martin, 1997, Mehran, 1995 and Yermack, 1995). In the more recent literature, though, there has been little evidence supporting a direct link between firm performance and executive compensation. Campbell and Wasley (1999) go so far as to suggest that the compensation package in place at Ralston Purina may have actually resulted in reduced 
performance. Though compensation packages are not generally separated into restricted stock and stock option components in these studies Guay (1999) finds evidence of the use of stock options, in particular, to manage executive sensitivity to stock risk. It is found that wealth convexity is most apparent where investment opportunities and the risk of under-investment are greatest, thus providing evidence of compensation packages being organised to reduce agency costs.

Fenn and Liang (2001) provide evidence that compensation packages have an impact on dividend policy where firms facing agency problems. In this case grants of restricted stock result in increased dividend payments while grants of stock options tend to be associated with reduced levels of dividends and greater levels of stock repurchases. Thus there may be a link between executive compensation packages and financial policy. One result in this paper is the identification of the direct between the executive compensation and executive attitude to leverage.

The valuation of non-standard options is another area of research in the executive remuneration literature. Examples include the impact of non-traditional stock option plans and indexed stock options (Johnson and Tian, 2000a and Johnson and Tian, 2000b). A further example is the valuation of options in the hands of risk averse, poorly diversified executives. This valuation problem is solved in Lambert, Larcker and Verrecchia (1991) with further application in Hall and Murphy (2000). The Lambert, Larcker and Verrecchia model is also used in this paper to value executive holding of 
restricted stock and stock options and the choice seems appropriate given the analysis of Kole (1997) and the discussion in Hall and Murphy (2000).

The value of a compensation package to a poorly diversified risk-averse executive is often dealt with in the management compensation literature yet it is rare that specific adjustment is made for firm leverage. ${ }^{1}$ In this paper it is assumed that a firm's debt portfolio may be approximated with one zero coupon bond with the same magnitude and duration as the firms portfolio of debt. Given this simplification the Lambert, Larcker and Verrecchia (1991) model is easily modified to include the impact of debt. The following discussion focuses on the marginal impact of security grants to the executive as well as the impact of security choice on the executive's total investment portfolio value. While section 2 describes the model, section 3 reports the results of numerical analysis with conclusions provided in section 4 .

\section{Model}

Executive wealth is assumed split between restricted stock, stock options, and risk free assets. It is assumed that the stock based securities, restricted stock and stock options, are issued to the executive as part of a compensation package or purchased on the market and that the executive holds no other risky securities. Generally there are restrictions placed on what the executive can do with these securities. 
Kole (1997) identifies four main areas of uniformity in the restrictions that apply to executive stock options. First, the exercise price is generally set equal to the market value of ordinary stock when the stock options are issued. An explanation for this result is provided in Hall and Murphy (2000). Second, the stock options generally refer to new stock. Third, the majority of the stock options expire around ten years after the grant. Finally, stock options are generally not transferable. Thus to value these contracts as if they were market traded securities, using a Black Scholes based valuation model, would be incorrect from the perspective of the executive who receives the stock option grant.

Stock, issued to executives, is generally restricted with respect to resale of the stock such that Kole (1997) describes these securities as "restricted stock". Kole (1997) notes that grants of restricted stock are generally most evident where innovative activity occurs, with "hold until retirement" clauses quite common for grants of restricted stock.

Given the restrictions on marketability and exercise evident with restricted stock and stock options issued to executives, the Lambert, Larcker and Verrecchia (1991) model seems appropriate for valuation of these securities. However, as indicated in Hall and Murphy (2000 and 2002), the Black Scholes pricing model still provides an estimate of the opportunity cost to the firm of issuing the securities. 
With the assumption of executive risk aversion and focusing on utility maximisation it is possible to value these securities in the hands of a "poorly" diversified risk-averse executive. The utility function used in this model has constant relative risk aversion and is defined as:

$U(w)= \begin{cases}1 /(1-\alpha) w^{1-\alpha} & \text {, if } \alpha \neq 1 \\ \log (w) & , \text { if } \alpha=1\end{cases}$

where $\alpha=$ constant relative risk aversion parameter, $\log (w)=$ natural $\log$ of $w$, $U(w)=$ Utility, a concave function of wealth $\left(U^{\prime}()>0,. U^{\prime \prime}()<0.\right)$ and $w=$ wealth.

The valuation approach used in this model involves the calculation of the expected utility of a particular compensation package focusing on discounted certainty equivalent to generate the present value of the executive's investment portfolio. The executive is assumed to hold wealth in the form of risk free assets as well as stock options and/or restricted stock in the firm. Thus the initial portfolio is written:

$\left(W+N_{s} S+N_{o} O\right)$

Where $N_{o}$ is number of stock options granted, $N_{s}$ is number of restricted stock granted, $O$ is the present value of a stock option in the hands of the executive, $S$ is the present value of the restricted stock in the hands of the executive and $W$ is the initial fixed wealth invested in the risk free rate.

The impact of leverage is included in the model by assuming that the firm's exposure to debt is approximated by zero-coupon debt with maturity set equal to 
the duration of the firm's portfolio of debt. Further, it is assumed that the firm is liquidated at the debt maturity date, consistent with Galai and Masulis (1976), Jensen and Meckling (1976). Finally, it is assumed that security grants have no dilution effect on existing security prices. The executive value of a grant of $N_{o}$ options is determined by solving for $N_{o} O$ in the following problem where portfolio value for the executive is defined:

$$
\begin{aligned}
\int_{0}^{\infty} U\left(W(1+R)^{T}\right. & \left.+N_{s} S^{*}+N_{o} O *\right) f(P) d P \\
& =\int_{0}^{\infty} U\left(\left(W+N_{o} O\right)(1+R)^{T}+N_{s} S *\right) f(P) d P
\end{aligned}
$$

where $B_{A}$ is the underlying asset beta, $O$ is the present value of the certainty equivalent for a stock options, $O^{*}$ is the value of an at the money stock option at time $T$ with strike price $X$ set equal to $S_{B}$, and with maturity payoff equal to $\operatorname{Max}\left(S^{*}-X, 0\right), P$ is the underlying asset value per stock, log normally distributed with mean return of $\left(R+B_{A} R P-0.5 \sigma^{2}\right) T$ and return variance of $\sigma^{2} T, R$ is the risk free rate of return, $R P$ is the market risk premium, $\sigma^{2}$ is the underlying asset return variance, $S^{*}$ is the value of stock in the firm at time T given debt $(D)$ or the $\operatorname{Max}(P-D, 0), S_{B}$ is the Black Scholes value of the stock given the strike price is set equal to the face value of the debt and $T$ is the time to liquidation of the firm.

Similarly, the executive value of a grant of $N_{s}$ restricted stock is determined by solving for $S$ where the value of the securities held in the firm is defined as: 


$$
\begin{aligned}
\int_{0}^{\infty} U\left(W(1+R)^{T}\right. & \left.+N_{s} S *+N_{o} O *\right) f(P) d P \\
& =\int_{0}^{\infty} U\left(\left(W+N_{s} S\right)(1+R)^{T}+N_{o} O *\right) f(P) d P
\end{aligned}
$$

where $N_{s} S$ is the present value of the certainty equivalent of the restricted stock. If the impact on executive wealth of changes in the proportion of restricted stock and stock options is required then the problem may be restated in terms of the value to the executive of the total portfolio as proportions of these securities are varied.

$$
\begin{aligned}
\int_{0}^{\infty} U\left(W(1+R)^{T}\right. & \left.+N_{s} S^{*}+N_{o} O^{*}\right) f(P) d P \\
& =U\left((W+\text { package })(1+R)^{T}\right)
\end{aligned}
$$

where package is the certainty equivalent of the combination of restricted stock and stock options in the portfolio

Thus the value that an executive places on restricted stock and stock options is a function of executive risk aversion, the level of restricted stock, stock options, risk free assets held, and firm leverage. Consistent with the extant options literature, the current value of the assets of the firm, the volatility of the underlying asset returns, the strike price of the stock options (assumed at-the-money here), the level of interest rates and the time to liquidation of the firm and its securities all have an impact on the value of these securities to the executive though not all of these impacts are discussed here in detail. 


\section{Analysis}

There are two approaches taken in the following analysis. In the first approach a small grant of restricted stock or restricted options is valued to assess the marginal impact of the grant on executive wealth given variation in existing security holdings and leverage. The second approach involves analysis of total executive wealth with analysis of sensitivity to changes in the proportion of restricted stock, stock options, leverage and volatility.

Before commencing analysis it is necessary to select parameters for the model described in Section 2. Following Hall and Murphy (2000), it is assumed that the underlying asset standard deviation is $30 \%$ per annum, the risk free rate of return is $6 \%$, the risk premium is $6.5 \%$, the underlying asset beta is 1.00 and the option strike price is set equal to the underlying asset price of $\$ 30.00$ where there is no debt. Where there is debt, the stock option strike price is still set equal to the market value of the restricted stock but in this case the restricted stock is valued as an option on the assets of the firm with strike price set equal to the face value of the zero coupon debt (Galai and Masulis, 1976, and Jensen and Meckling, 1976).

\section{1. $\quad$ Changes in executive wealth at the margin}

\subsubsection{A grant of $\$ 1,000$ worth of stock options or restricted stock}

Calculation of the marginal cost to the firm and the marginal benefit to the executive of grants of either restricted stock or stock options allows comparisons to be made between these two security types. To assess the impact of a grant of restricted stock or stock 
options from an executive’s point of view, the firm is assumed to issue $\$ 1,000$ worth of either restricted stock or stock options. The opportunity cost to the firm of the security issue is determined using the Black Scholes option pricing model and this opportunity cost is divided into $\$ 1,000$ to determine the number of securities allocated to the executive in the $\$ 1,000$ grant. The number of securities is then multiplied by the value of the grant to the executive using the adjusted Lambert, Larcker and Verrecchia model. It is assumed that the executive currently holds an investment portfolio with market value of \$5 million. This analysis draws upon Hall and Murphy (2000), highlighting the relationship between the percentage of total initial executive wealth $(0 \%, 33 \%$. $50 \%$ and $66 \%$ ) held as restricted stock or stock options, the level of executive risk aversion (relative risk aversion parameter of 1,2 or 3 ), the level of debt as a percentage of the underlying assets held by the firm $(0 \%, 33 \%, 50 \%$ and $66 \%)$ and the value to an executive of a grant of $\$ 1,000$ in either restricted stock or stock options.

[Insert Tables 1 and 2 here]

The stock options are assumed to be at the money (Hall and Murphy, 2000 and Kole, 1997) and so the exercise price of these options varies with the Black Scholes value of the stock, determined by the level of debt held by the company. The current underlying stock price, and stock option exercise price, is $\$ 30.00$ for the no debt example, $\$ 24.64$ for 33\% debt, $\$ 22.20$ for $50 \%$ debt and $\$ 20.15$ for the situation where debt accounts for $66 \%$ of the underlying asset value. The Black Scholes option values for at-the-money options 
written on the stock are $\$ 16.55$ for no debt, $\$ 15.21$ for 33\% debt, $\$ 14.50$ for $50 \%$ debt and $\$ 13.81$ for $66 \%$ debt.

The value of stock options and restricted stock to the executive differs considerably from the opportunity cost to the firm (Black Scholes value). For example the value of these securities to the executive decreases as the level of relative risk aversion increases. The decrease is relatively small where there are few stock options or little restricted stock in the executive's portfolio but as the percentage that these securities represent of total executive wealth increases the decrease in value to the executive becomes more noticeable. These results are also noted in Lambert, Larcker and Verrecchia (1991) and Hall and Murphy (2000) for stock options though the impact on restricted stock is not analysed in these papers because of the assumption of zero leverage. Executives with greater levels of risk aversion place a lower value on stock options and on restricted stock than executives with lower levels of risk aversion. For example, in Table 1, with no debt and restricted stock set equal to $33 \%$ of initial wealth, an increase in the risk aversion parameter from 1 to 3 results in a 56\% drop in the value to an executive of a \$1,000 grant of stock options, from $\$ 1,397.35$ to $\$ 621.40$. This effect is also observed for grants of restricted stock with a decrease of $37 \%$ in value to the executive. Continuing with this example and given the implicit market value of $\$ 1,000.00$, the less risk-averse executive (constant relative risk aversion of one) places a greater value on the option grant than the market while the more risk-averse executive (constant relative risk aversion of three) values the options less than the market. Similar results are apparent in Table 2 where the 
executive is assumed to hold varying levels of stock options and the value to an executive of a $\$ 1,000$ grant of restricted stock or stock options is estimated.

\subsubsection{Comparison of the impact of a stock option grant and a restricted stock grant}

The choice between restricted stock and stock options is often argued to be important. Tables 1 and 2 provide a comparison of the value to an executive of a \$1,000 grant of these securities. Regardless of whether the executive holds stock options or restricted stock the relative value of a grant of stock options versus a grant of restricted stock varies with the level of risk aversion, restricted stock and stock option holdings and corporate leverage. An executive with low levels of investment in the firm's securities tends to value stock options more highly than restricted stock but as the level of investment in the firm sensitive securities (restricted stock or stock options) increases this ranking is reversed with restricted stock eventually being valued more highly than stock options at the margin. Though the magnitude of this effect varies with the level of risk aversion and leverage, Figure 1 provides an indication of the relationship between the value to the executive and the level of executive investment in restricted stock. In this example leverage is set at $33 \%$ of total assets and constant relative risk aversion is set equal to one. It is apparent that as the proportion of total wealth held as restricted stock increases the value to the executive of additional restricted stock decreases. The key result here is that the value of restricted stock declines at a lesser rate than the decline in stock option value to the executive resulting in the marginal value to the executive of restricted stock eventually exceeding the marginal value placed on stock options. This result is evident whether initial wealth consists of a combination of risk free assets and restricted stock or 
a combination of risk free assets and stock options, though greater variation in the executive value of the grant is evident in the latter case.

[Insert Figure 1 here]

\subsubsection{Impact of leverage}

As indicated in Tables 1 and 2, leverage may have an impact on the value of additional grants of restricted stock or stock options to the executive. The level of existing firm sensitive securities held by the executive and the level of risk aversion interact with leverage. As the level of firm sensitive securities increases from zero, the leverage effect on executive security value varies from increasing, to neutral and then to decreasing. At low levels of risk aversion and very low levels of restricted stock or option holdings, increasing leverage actually results in increasing executive value placed on the security grant. As the level of firm sensitive securities increases, and to a lesser extent the level of risk aversion increases, the positive relationship between leverage and value placed on the security by the executive changes to a fairly neutral relationship and then to a negative relationship. Figure 2 highlights this effect using a grant of $\$ 1,000$ worth of stock options and focussing on the impact of increasing levels of restricted stock and leverage. The level of risk aversion is assumed fixed at a value of one.

[Insert Figure 2 here] 
The results in Figure 2 suggest that inclusion of restricted stock and stock options in an executive's compensation package may generate a source of agency costs with executives choosing debt levels that maximise the executive's utility function rather than maximising firm value. It is apparent that the level of diversification of executive wealth may have an impact on executive perceptions of the optimal level of debt. As the level of restricted stock and stock options held by an executive increases the executive may initially prefer to increase debt but as the level of stock and options increases further the preference for debt changes to indifference and then finally to debt aversion. This may provide one explanation for the lower than expected leverage observed for US firms given the tax benefits of debt (Graham, 2000).

\subsection{Total executive wealth, compensation package, leverage and volatility}

Table 3, Panels A, B and C, provide an alternative analysis of the value to the executive of grants of restricted stock and stock options. The approach taken here is to view the choice between risk free assets, restricted stock and stock options in terms of the value to the risk-averse executive of the total portfolio. The impact of changing the proportions of these securities is then estimated. The executive is assumed to have $\$ 5$ million in wealth that is split between risk free assets, restricted stock and stock options. As the proportion of wealth invested in the three asset types varies the number of restricted stock and the number of stock options are estimated by dividing the total amount allocated to these asset types by the appropriate estimate of security opportunity cost (the Black Scholes value). The value to the risk-averse executive of the new $\$ 5$ million portfolio is then estimated using the model described in equation (5). 
[Insert Table 3, Panels A, B and C]

As indicated in Table 3, higher leverage generally results in a lower executive value being attached to the portfolio with the exception of Table 3, Panel A, where 33\% (and to some extent 50\%) of wealth is invested in restricted stock and stock options. The impact of increasing leverage provides a rather complex story given low investment in restricted stock and stock options combined with low relative risk aversion. In this case, increasing leverage may either increase or decrease the value of the portfolio depending on the relative level of stock options held. If the executive holds all $33 \%$ of firm sensitive investment as stock options then increasing leverage results in decreasing the value of the portfolio to the executive but if the stock options are replaced by restricted stock, leverage increases eventually result in increased wealth. Further, given zero leverage, the value to the executive of the portfolio decreases as stock options are replaced by restricted stock. However if leverage is set at $66 \%$, the executive value of the portfolio increases as stock options are replaced by restricted stock. This is not a common result in Table 3 but it does provide quite graphic evidence of the impact of parameter choice on the analysis. Perhaps the major point of this analysis is that assumptions about the level of risk aversion do count. Figure 4, with relative risk aversion set to three, provides a more representative example of portfolio valuation based on the detail in Table 3 with replacement of stock options by restricted stock resulting in increased executive value of the portfolio and increased leverage resulting in decreased value of the portfolio to the executive. 
[Insert Figures 3 and 4 here]

The impact of changes in the variance of the underlying asset returns is reported in Table 4 and Figures 5 and 6 . In this example leverage is held constant at $40 \%$, the investment in firm sensitive securities is set to 33\%, the proportion invested in stock options includes $0 \%, 34 \%, 50 \%, 67 \%$ and $100 \%$ and the standard deviation of underlying asset returns is set to values of $10 \%, 30 \%, 50 \%, 70 \%$ and $90 \%$ respectively. Relative risk aversion is set to one in Panel A, two in Panel B and three in Panel C of Table 4. The level of risk aversion and the level of investment in stock options are critical in assessing the impact on executive wealth. As indicated in Table 4, Panel A, given relative risk aversion equal to one and low exposure to stock or options (33\% of wealth), the value to the executive is increasing in volatility regardless of whether the security is an stock option or restricted stock. As the exposure to restricted stock or stock options is increased (66\% of wealth) there is some variation in the results. For low levels of stock options the value to the executive of the exposure to the firm's securities is also increasing in volatility but as the level of options approaches $100 \%$ there is a non-linear relationship between value and volatility, initially decreasing and finally increasing with increases in volatility. Where relative risk aversion is set equal to three (Table 4, Panel C) the value of the portfolio to the executive decreases in volatility regardless of the security choice.

[Insert Table 4 and Figures 5 and 6 here] 
Thus there is some change in the value that an executive places on a portfolio with variation in the mix of the restricted stock and stock options. In Figure 5, with relative risk aversion set to one, as the proportion of options in the portfolio increases the value of the portfolio to the executive tends to increase. In Figure 6, with relative risk aversion set to three, as the proportion of options in the portfolio increases the value of the portfolio to the executive is either stable or tends to decrease. Further, the greater the level of riskaversion the more likely the executive will favour restricted stock over stock options. This is not unexpected though it is important to note that a change in relative risk aversion from one to three can lead to a reversal of the relationship between the level of risk aversion and security mix in determining the value of the portfolio to the executive.

These results have implications for the derivative use literature which has generally argued that derivative use will be increasing in restricted stock holdings and decreasing in stock option holdings (Geczy, Minton and Schrand, 1997, Rajgopal and Shevlin 2000, Smith and Stulz, 1985 and Tufano, 1996). It has been suggested that executives who hold options will prefer greater volatility and so will choose not to use derivatives for hedging purposes. Essentially, the relationship between restricted stock, stock options and executive wealth is quite complex, being dependent on executive risk aversion, leverage and the composition of the executive's portfolio. Perhaps the inconsistency in the Logit estimates of the managerial option ownership coefficient in Tufano (1996) and Geczy, Minton and Schrand (1997) provides some indication of the impact of this complexity. Certainly the analysis here suggests a more complex relationship than that posited in Smith and Stulz (1985). 


\section{Conclusions}

It is apparent that compensation package design is a complex process. This paper identifies a number of interactions between leverage, the level of executive relative risk aversion, underlying asset volatility and the components of the executive's wealth. The impact of leverage has received little attention in the management compensation literature and introduction of leverage increases the richness of the management compensation valuation problem. For example restricted stock is now valued as an option on the assets of the firm and the stock options are valued as options written on options and these options are valued using an adjusted form of the Lambert, Larcker and Verrecchia model, extended to include the impact of leverage.

The level of risk aversion is an important factor in identifying the compensation impact of a grant of securities to an executive. Executives with low levels of risk aversion place a higher value on grants of restricted stock or stock options than more risk-averse executives and, at least at an individual level, for executives with lower levels of risk aversion the value placed on these securities often exceeds the Black Scholes based opportunity cost of the issues. As the level of risk aversion increases the value executives place on additional grants of these securities eventually falls below the Black Scholes based estimates. This suggests that compensation packages based solely on restricted stock or stock options may not be particularly cost effective for more highly risk-averse executives 
The levels of risk aversion, the components of the executive portfolio (stock options, restricted stock and risk free assets), underlying asset volatility and firm leverage all play a part in executive compensation agreements. A key result in this paper is that as the level of risk aversion increases executives eventually prefer to reduce leverage to maximise wealth. Thus executive compensation agreements may help to explain the unexpectedly low levels of debt adopted by US corporations and the perceived failure to capture all available debt tax shields. Another result relates to the impact of volatility on executive compensation agreements. It is often argued in the derivative use literature that executives who hold stock options will prefer volatility and will choose not to hedge. This result is very much dependent on the level of risk aversion exhibited by the executive and also the level of restricted stock and stock options held by the executive. While it may be true for executives with low levels of risk aversion this is not the case for executives with higher levels of risk aversion. .

The introduction of debt generates further insight into the perception that poorly diversified risk-averse executives might have of particular compensation packages. It also creates the opportunity to review the impact of financial policy decisions such as leverage choice and derivative use on these executives. 


\section{References}

Acharya, V. V.; K. John, and R. K. Sundaram, 2000, On the Optimality of resetting Executive Stock Options, Journal of Financial Economics, 57, 65-101.

Brenner, M.; R. Sundaram; and D. Yermack, 2000, Altering the Terms of Executive Stock Options, Journal of Financial Economics, 57, 103-128.

Campbell, C. and E. Wasley, 1999, Stock-Based Incentive Contracts and Managerial Performance: the Case of Ralston Purina Company, Journal of Financial Economics, 51, $195-217$.

Chance, D.; R. Kumar; and R. Todd, 2000, The Repricing of Executive Stock Options, Journal of Financial Economics, 57, 129-154.

Cooper, I. and A. Mello, 1999, Corporate Hedging: The Relevance of Contract Specifications and Banking Relationships, European Economic Review, 2, 195-223.

Core, J.; R. Holthausen; and D. Larcker, 1999, Corporate Governance, Chief Executive Officer Compensation and Firm Performance, Journal of Financial Economics, 51, 371406.

Demsetz, H. and B. Villalonga, 2000, Ownership Structure and Corporate Performance, working paper. 
Fenn, G. and N. Liang, 2001, Corporate Payout Policy and Managerial Stock Incentives, Journal of Financial Economics, 60, 45-72.

Galai, D. and R. Masulis, 1976, The Option Pricing Model and the Risk Factor of Stock, Journal of Financial Economics, 3, 53-81.

Garvey, G., 1997, Marketable Incentive Contracts and Capital Structure Relevance, Journal of Finance, 52, 353-378.

Graham, J., 2000, How Big are the Tax Benefits of Debt? Journal of Finance, 55, 19011941.

Geczy, C.; B. Minton; and C. Schrand, 1997, Why Companies Use Currency Derivatives? Journal of Finance, 52, 1323-1354.

Guay, W., 1999, The Sensitivity of CEO Wealth to Equity Risk: An Analysis of the Magnitude and Determinants, Journal of Financial Economics, 53, 43-71.

Hall, B. and K. Murphy, 2000, Optimal Exercise Prices for Executive Stock Options, American Economic Review, 90, 209-214. 
Hall, B. and K. Murphy, 2002, Stock options for Undiversified Executives, Journal of Accounting \& Economics, 33, 3-42.

Himmelberg, C.; R. Hubbard; and D. Palia, 1999, Understanding the Determinants of Managerial Ownership and the Link Between Ownership and Performance, Journal of Financial Economics, 53, 353-384.

Jensen, M. and W. Meckling, 1976, The Theory of the Firm: Managerial behavior, agency costs, and Ownership Structure, Journal of Financial Economics, 3, 305-360.

John, T. and J. Kose, 1993, Top-Management Compensation and Capital Structure, Journal of Finance, 48, pp. 949-974.

Johnson, S. and Y. Tian, 2000a, The Value and Incentive Effects of Nontraditional Executive Stock Option Plans, Journal of Financial Economics, 57, 3-34.

Johnson, S. and Y. Tian, 2000b, Indexed Executive Stock Options, Journal of Financial Economics, 57, 35-64.

Kole, S., 1997, The Complexity of Compensation Contracts, Journal of Financial Economics, 43, 79-104. 
Lambert, R.; D. Larcker; and R. Verrecchia, 1991, Portfolio Considerations in Valuing Executive Compensation, Journal of Accounting Research, 29, 129-149.

Loderer, C. and K. Martin, 1997, Executive Stock Ownership and Performance Tracking Faint Traces, Journal of Financial Economics, 45, 223-255.

Mehran, H., 1992, Executive incentive Plans, Corporate Control, and Capital Structure, Journal of Financial and Quantitative Analysis, 27, 539-560.

Mehran, H., 1995, Executive Compensation Structure, Ownership and Firm Performance, Journal of Financial Economics, 38, 163-184.

Rajgopal, S. and T. Shevlin, 2000, Stock Option Compensation and Risk Taking: The Case of Oil and Gas Producers, working paper.

Smith, C. and R. Stulz, 1985, The Determinants of Companys Hedging Policies, Journal of Financial and Quantitative Analysis, 20, 391-405.

Tufano, P., 1996, Who Manages Risk? An Empirical Examination of Risk Management Practices in the Gold Mining Industry, Journal of Finance, 51, 1097-1137.

Yermack, D., 1995, Do Corporations Award CEO Stock Options Effectively? Journal of Financial Economics, 39, 237-269. 


\section{Table 1}

\section{Value to a risk-averse executive who holds varying levels of restricted stock of a grant of $\$ 1,000$ in restricted stock or at-the-money stock options}

\begin{tabular}{|c|c|c|c|c|c|c|}
\hline $\begin{array}{c}\text { Relative risk } \\
\text { aversion }\end{array}$ & $\begin{array}{c}\% \text { restricted } \\
\text { stock holding }\end{array}$ & Grant & 0.00 & 0.33 & $\begin{array}{c}\text { Leverage } \\
0.50 \\
\end{array}$ & 0.66 \\
\hline 1 & $\begin{array}{l}0 \% \\
0.33 \% \\
0.50 \% \\
0.66 \%\end{array}$ & $\begin{array}{l}\text { restricted stock } \\
\text { stock options } \\
\text { restricted stock } \\
\text { stock options } \\
\text { restricted stock } \\
\text { stock options } \\
\text { restricted stock } \\
\text { stock options }\end{array}$ & $\begin{array}{r}1812.60 \\
2355.82 \\
1263.86 \\
1397.35 \\
1128.44 \\
1172.77 \\
1016.36 \\
994.57\end{array}$ & $\begin{array}{r}1984.10 \\
2436.13 \\
1244.35 \\
1302.64 \\
1062.34 \\
1046.43 \\
902.60 \\
836.87\end{array}$ & $\begin{array}{r}2079.67 \\
2482.38 \\
1219.90 \\
1246.60 \\
1011.52 \\
974.72 \\
826.87 \\
751.47\end{array}$ & $\begin{array}{r}2169.50 \\
2529.72 \\
1188.89 \\
1192.52 \\
957.83 \\
908.24 \\
754.71 \\
676.59\end{array}$ \\
\hline 2 & $\begin{array}{l}0 \% \\
0.33 \% \\
0.50 \% \\
0.66 \%\end{array}$ & $\begin{array}{l}\text { restricted stock } \\
\text { stock options } \\
\text { restricted stock } \\
\text { stock options } \\
\text { restricted stock } \\
\text { stock options } \\
\text { restricted stock } \\
\text { stock options }\end{array}$ & $\begin{array}{r}1812.12 \\
2354.30 \\
972.53 \\
905.92 \\
801.57 \\
641.34 \\
664.58 \\
449.56\end{array}$ & $\begin{array}{r}1983.40 \\
2434.36 \\
872.18 \\
763.99 \\
650.65 \\
485.50 \\
466.49 \\
289.13\end{array}$ & $\begin{array}{r}2078.80 \\
2480.44 \\
804.88 \\
688.19 \\
563.29 \\
410.45 \\
369.83 \\
223.45\end{array}$ & $\begin{array}{r}2168.46 \\
2527.60 \\
738.21 \\
620.27 \\
486.65 \\
349.17 \\
296.49 \\
176.55\end{array}$ \\
\hline 3 & $\begin{array}{l}0 \% \\
0.33 \% \\
0.50 \% \\
0.66 \%\end{array}$ & $\begin{array}{l}\text { restricted stock } \\
\text { stock options } \\
\text { restricted stock } \\
\text { stock options } \\
\text { restricted stock } \\
\text { stock options } \\
\text { restricted stock } \\
\text { stock options }\end{array}$ & $\begin{array}{r}1811.65 \\
2352.79 \\
795.40 \\
621.40 \\
619.92 \\
372.95 \\
484.19 \\
213.08 \\
\end{array}$ & $\begin{array}{r}1982.69 \\
2432.59 \\
656.44 \\
475.83 \\
438.50 \\
238.27 \\
271.11 \\
102.15 \\
\end{array}$ & $\begin{array}{r}2077.94 \\
2478.51 \\
574.35 \\
405.16 \\
349.36 \\
183.87 \\
191.11 \\
68.96 \\
\end{array}$ & $\begin{array}{r}2167.42 \\
2525.49 \\
500.35 \\
346.36 \\
280.47 \\
144.67 \\
139.98 \\
49.24 \\
\end{array}$ \\
\hline
\end{tabular}

Note: Executive wealth is currently $\$ 5$ million split between risk free assets and restricted stock $(0 \%, 33 \%$, $50 \%, 66 \%)$. It is assumed that there is a grant made to the executive of $\$ 1000$ in either stock options or restricted stock. The cost to the firm is $\$ 1,000$ in all cases and the number of options or restricted stock granted is calculated by dividing $\$ 1,000$ by the Black Scholes value of the security. The underlying asset value per stock is $\$ 30.00$ and asset returns are log-normally distributed with expected value of $(r f+B R P$ $\left.0.5 \sigma^{2}\right) T$ and variance $\sigma^{2} T\left(r f=0.06, B=1, R P=0.65, \sigma^{2}=0.09\right.$ and $\left.T=10\right)$. The level of debt is set at zero, $33 \%, 50 \%$ and $66 \%$ of the underlying asset value. Option strike prices are set at the money. Where there is no debt the asset value per stock is also the stock price at the beginning of the period and so the strike price is set to $\$ 30.00$. With non-zero debt the current stock price and strike price are calculated using the Black Scholes option pricing model with the option strike price set equal to the face value of debt. This gives rise to at the money stock options with strike prices of $\$ 24.64, \$ 22.20$ and $\$ 20.15$ for the debt percentages 33\%, 50\% and 66\% respectively. The risk aversion parameter takes on values of 1,2 and 3 . 


\section{Table 2}

\section{Value to a risk-averse executive who holds with varying levels of stock options of a grant of $\$ 1,000$ in restricted stock or at-the-money stock options}

\begin{tabular}{|c|c|c|c|c|c|c|}
\hline $\begin{array}{l}\text { Relative risk } \\
\text { aversion }\end{array}$ & $\begin{array}{l}\text { \% option } \\
\text { holding }\end{array}$ & Grant & 0.00 & 0.33 & $\begin{array}{c}\text { everage } \\
0.50\end{array}$ & 0.66 \\
\hline 1 & $\begin{array}{r}0 \% \\
0.33 \% \\
0.50 \% \\
0.66 \%\end{array}$ & $\begin{array}{l}\text { restricted stock } \\
\text { stock options } \\
\text { restricted stock } \\
\text { stock options } \\
\text { restricted stock } \\
\text { stock options } \\
\text { restricted stock } \\
\text { stock options }\end{array}$ & $\begin{array}{r}1812.60 \\
2355.82 \\
1098.03 \\
1105.51 \\
937.40 \\
838.31 \\
798.02 \\
614.48\end{array}$ & $\begin{array}{r}1984.10 \\
2436.13 \\
1095.34 \\
1064.07 \\
903.51 \\
786.67 \\
740.43 \\
560.65\end{array}$ & $\begin{array}{r}2079.67 \\
2482.38 \\
1085.37 \\
1039.18 \\
876.83 \\
757.37 \\
702.08 \\
531.56\end{array}$ & $\begin{array}{r}2169.50 \\
2529.72 \\
1069.45 \\
1013.14 \\
846.33 \\
727.90 \\
662.40 \\
503.27\end{array}$ \\
\hline 2 & $\begin{array}{l}0 \% \\
0.33 \% \\
0.50 \% \\
0.66 \%\end{array}$ & $\begin{array}{l}\text { restricted stock } \\
\text { stock options } \\
\text { restricted stock } \\
\text { stock options } \\
\text { restricted stock } \\
\text { stock options } \\
\text { restricted stock } \\
\text { stock options }\end{array}$ & $\begin{array}{r}1812.12 \\
2354.30 \\
799.07 \\
600.75 \\
640.68 \\
352.94 \\
527.81 \\
189.50\end{array}$ & $\begin{array}{r}1983.40 \\
2434.36 \\
742.95 \\
545.11 \\
564.43 \\
306.37 \\
442.29 \\
157.52\end{array}$ & $\begin{array}{r}2078.80 \\
2480.44 \\
704.55 \\
514.49 \\
517.46 \\
282.28 \\
392.67 \\
141.91\end{array}$ & $\begin{array}{r}2168.46 \\
2527.60 \\
663.97 \\
484.33 \\
471.60 \\
259.54 \\
346.74 \\
127.71\end{array}$ \\
\hline 3 & $\begin{array}{l}0 \% \\
0.33 \% \\
0.50 \% \\
0.66 \%\end{array}$ & $\begin{array}{l}\text { restricted stock } \\
\text { stock options } \\
\text { restricted stock } \\
\text { stock options } \\
\text { restricted stock } \\
\text { stock options } \\
\text { restricted stock } \\
\text { stock options }\end{array}$ & $\begin{array}{r}1811.65 \\
2352.79 \\
653.70 \\
366.45 \\
524.61 \\
177.99 \\
446.44 \\
77.51\end{array}$ & $\begin{array}{r}1982.69 \\
2432.59 \\
579.42 \\
318.35 \\
439.68 \\
146.96 \\
358.39 \\
61.34\end{array}$ & $\begin{array}{r}2077.94 \\
2478.51 \\
532.99 \\
293.22 \\
390.17 \\
131.79 \\
309.18 \\
53.86\end{array}$ & $\begin{array}{r}2167.42 \\
2525.49 \\
487.13 \\
269.34 \\
344.19 \\
117.98 \\
265.32 \\
47.27\end{array}$ \\
\hline
\end{tabular}

Note: Executive wealth is currently $\$ 5$ million split between risk free assets and stock options ( $0 \%$, 33\%, $50 \%, 66 \%)$. It is assumed that there is a grant made to the executive of $\$ 1000$ in either stock options or restricted stock. The cost to the firm is $\$ 1,000$ in all cases and the number of options or restricted stock granted is calculated by dividing $\$ 1,000$ by the Black Scholes value of the security. The underlying asset value per stock is $\$ 30.00$ and asset returns are log-normally distributed with expected value of $(r f+B R P-$ $\left.0.5 \sigma^{2}\right) T$ and variance $\sigma^{2} T\left(r f=0.06, B=1, R P=0.65, \sigma^{2}=0.09\right.$ and $\left.T=10\right)$. The level of debt is set at zero, $33 \%, 50 \%$ and $66 \%$ of the underlying asset value. Option strike prices are set at the money. Where there is no debt the asset value per stock is also the stock price at the beginning of the period and so the strike price is set to $\$ 30.00$. With non-zero debt the current stock price and strike price are calculated using the Black Scholes option pricing model with the option strike price set equal to the face value of debt. This gives rise to at the money stock options with strike prices of $\$ 24.64, \$ 22.20$ and $\$ 20.15$ for the debt percentages 33\%, 50\% and 66\% respectively. The risk aversion parameter takes on values of 1, 2 and 3 . 


\section{Table 3}

Impact of leverage on the value (\$ millions) to a risk-averse executive of a portfolio including restricted stock and stock options Panel A: Constant relative risk aversion of one (CRRA = 1)

\begin{tabular}{l|cccccc}
\hline Portfolio \% in stock and options & $\begin{array}{c}\text { Restricted Stock } \\
\%\end{array}$ & $\begin{array}{c}\text { Stock option } \\
\%\end{array}$ & 0.00 & $\begin{array}{c}\text { Leverage } \\
0.33\end{array}$ & 0.50 & 0.66 \\
\hline \multirow{5}{*}{$33 \%$} & & & & & & \\
& & & & & & \\
& 0.00 & 1.00 & 5.91 & 5.89 & 5.88 & 5.86 \\
& 0.33 & 0.67 & 5.89 & 5.90 & 5.90 & 5.89 \\
& 0.50 & 0.50 & 5.88 & 5.90 & 5.91 & 5.90 \\
& 0.66 & 0.34 & 5.86 & 5.90 & 5.91 & 5.91 \\
$50 \%$ & 1.00 & 0.00 & 5.79 & 5.87 & 5.90 & 5.92 \\
& & & & & & \\
& 0.00 & 1.00 & 5.87 & 5.81 & 5.76 & 5.72 \\
& 0.33 & 0.67 & 5.95 & 5.91 & 5.88 & 5.83 \\
& 0.50 & 0.50 & 5.98 & 5.95 & 5.92 & 5.88 \\
$66 \%$ & 0.66 & 0.34 & 5.99 & 5.98 & 5.96 & 5.92 \\
& 1.00 & 0.00 & 5.97 & 6.02 & 6.01 & 5.98 \\
& & & & & & \\
& 0.00 & 1.00 & 5.57 & 5.44 & 5.36 & 5.27 \\
& 0.33 & 0.67 & 5.81 & 5.69 & 5.60 & 5.51 \\
& 0.50 & 0.50 & 5.90 & 5.80 & 5.71 & 5.61 \\
& 0.66 & 0.34 & 5.97 & 5.88 & 5.79 & 5.69 \\
& 1.00 & 0.00 & 6.04 & 6.00 & 5.93 & 5.83 \\
& & & & & & \\
\hline
\end{tabular}




\section{Table 3}

Impact of leverage on the value (\$ millions) to a risk-averse executive of a portfolio including restricted stock and stock options Panel B: Constant relative risk aversion of two (CRRA = 2)

\begin{tabular}{l|ccccccc}
\hline $\begin{array}{c}\text { Portfolio \% in stock and } \\
\text { options }\end{array}$ & $\begin{array}{c}\text { Restricted Stock } \\
\%\end{array}$ & $\begin{array}{c}\text { Stock option } \\
\%\end{array}$ & 0.00 & $\begin{array}{c}\text { Leverage } \\
0.33\end{array}$ & 0.50 & 0.66 \\
\hline \multirow{5}{*}{$33 \%$} & & & & & & & \\
& & & & & & \\
& 0.00 & 1.00 & 5.17 & 5.11 & 5.06 & 5.02 \\
& 0.33 & 0.67 & 5.29 & 5.22 & 5.18 & 5.13 \\
& 0.50 & 0.50 & 5.34 & 5.28 & 5.23 & 5.18 \\
& 0.66 & 0.34 & 5.38 & 5.32 & 5.28 & 5.23 \\
$50 \%$ & 1.00 & 0.00 & 5.44 & 5.40 & 5.36 & 5.31 \\
& & & & & & \\
& 0.00 & 1.00 & 4.60 & 4.47 & 4.39 & 4.32 \\
& 0.33 & 0.67 & 4.89 & 4.74 & 4.64 & 4.54 \\
& 0.50 & 0.50 & 5.02 & 4.86 & 4.75 & 4.64 \\
$66 \%$ & 0.66 & 0.34 & 5.13 & 4.96 & 4.85 & 4.73 \\
& 1.00 & 0.00 & 5.32 & 5.16 & 5.03 & 4.90 \\
& & & & & & \\
& 0.00 & 1.00 & 3.73 & 3.55 & 3.45 & 3.36 \\
& 0.33 & 0.67 & 4.26 & 4.00 & 3.84 & 3.69 \\
& 0.50 & 0.50 & 4.50 & 4.20 & 4.01 & 3.84 \\
& 0.66 & 0.34 & 4.70 & 4.37 & 4.16 & 3.96 \\
& 1.00 & 0.00 & 5.06 & 4.69 & 4.44 & 4.20 \\
\hline
\end{tabular}




\section{Table 3}

\section{Impact of leverage on the value (\$ millions) to a risk-averse executive of a portfolio including restricted stock and stock options Panel C: Constant relative risk aversion of three (CRRA = 3)}

\begin{tabular}{l|ccccccc}
\hline $\begin{array}{c}\text { Portfolio \% in stock and } \\
\text { options }\end{array}$ & $\begin{array}{c}\text { Restricted Stock } \\
\%\end{array}$ & $\begin{array}{c}\text { Stock option } \\
\%\end{array}$ & 0.00 & $\begin{array}{c}\text { Leverage } \\
0.33\end{array}$ & 0.50 & 0.66 \\
\hline \multirow{5}{*}{$33 \%$} & & & & & & & \\
& 0.00 & 1.00 & 4.74 & 4.66 & 4.61 & 4.56 \\
& 0.33 & 0.67 & 4.91 & 4.82 & 4.76 & 4.70 \\
& 0.50 & 0.50 & 5.00 & 4.89 & 4.83 & 4.76 \\
& 0.66 & 0.34 & 5.07 & 4.96 & 4.89 & 4.82 \\
& 1.00 & 0.00 & 5.19 & 5.09 & 5.01 & 4.93 \\
& & & & & & \\
$50 \%$ & 0.00 & 1.00 & 3.94 & 3.82 & 3.75 & 3.69 \\
& 0.33 & 0.67 & 4.30 & 4.12 & 4.01 & 3.91 \\
& 0.50 & 0.50 & 4.47 & 4.26 & 4.13 & 4.01 \\
& 0.66 & 0.34 & 4.62 & 4.38 & 4.24 & 4.10 \\
& 1.00 & 0.00 & 4.90 & 4.62 & 4.44 & 4.27 \\
& & & & & & \\
& 0.00 & 1.00 & 2.94 & 2.80 & 2.73 & 2.67 \\
& 0.33 & 0.67 & 3.51 & 3.23 & 3.09 & 2.96 \\
& 0.50 & 0.50 & 3.77 & 3.43 & 3.24 & 3.08 \\
& 0.66 & 0.34 & 4.00 & 3.59 & 3.37 & 3.18 \\
& 1.00 & 0.00 & 4.44 & 3.90 & 3.60 & 3.35 \\
\hline
\end{tabular}

Note: Panels A, B and C of this table report the value to a risk-averse executive (constant relative risk aversion of one, two and three respectively) of various combinations of the risk free assets and restricted stock and stock options issued by the firm given different firm leverage ratios. It is assumed that the executive has an initial wealth of $\$ 5$ million in risk free assets. The composition of the portfolio is then altered without changing the total market value (Black Scholes value) of the portfolio. Essentially a package of restricted stock and stock options valued at market replaces existing investments such that the package accounts for $33 \%, 50 \%$ or $66 \%$ of the total portfolio market value of $\$ 5$ million. The stock option and restricted stock package is then split between restricted stock and stock options in the proportions $100 \%$ and $0 \%, 67 \%$ and $33 \%, 50 \%$ and $50 \%, 34 \%$ and $66 \%$ and $0 \%$ and $100 \%$. The size of the stock and option package appears in the first column of the table while the percentage of stock options in the package appears in the next column. (The percentage of restricted stock is simply one minus the percentage of stock options in the package.) The last four columns include the risk-averse executive value attached to the portfolio for four leverage percentages. Leverage is expressed as the percentage of value of debt to the value of underlying assets per share $(0 \%, 33 \%, 50 \%, 66 \%)$. 
Table 4

Impact of volatility on the value (\$ millions) to a risk-averse executive of a portfolio including restricted stock and stock options Panel A: Constant relative risk aversion of one (CRRA = 1)

\begin{tabular}{c|ccccccc}
\hline $\begin{array}{c}\text { Portfolio \% in } \\
\text { stock and } \\
\text { options }\end{array}$ & $\begin{array}{c}\text { Restricted stock } \\
\%\end{array}$ & $\begin{array}{c}\text { Stock option } \\
\%\end{array}$ & 0.10 & 0.30 & 0.50 & 0.70 & 0.90 \\
\hline \multirow{3}{*}{$33 \%$} & & & & & & & \\
& 0.00 & 1.00 & 5.70 & 5.89 & 6.61 & 7.70 & 9.29 \\
& 0.33 & 0.67 & 5.61 & 5.90 & 6.65 & 7.59 & 8.82 \\
& 0.50 & 0.50 & 5.55 & 5.90 & 6.66 & 7.53 & 8.54 \\
& 0.66 & 0.34 & 5.50 & 5.90 & 6.67 & 7.47 & 8.26 \\
$50 \%$ & 1.00 & 0.00 & 5.38 & 5.87 & 6.68 & 7.31 & 7.59 \\
& & & & & & & \\
& 0.00 & 1.00 & 5.91 & 5.81 & 6.48 & 7.61 & 9.31 \\
& 0.33 & 0.67 & 5.81 & 5.91 & 6.62 & 7.58 & 8.87 \\
& 0.50 & 0.50 & 5.76 & 5.95 & 6.68 & 7.55 & 8.60 \\
$66 \%$ & 0.66 & 0.34 & 5.69 & 5.98 & 6.73 & 7.51 & 8.33 \\
& 1.00 & 0.00 & 5.54 & 6.02 & 6.81 & 7.40 & 7.63 \\
& & & & & & & \\
& 0.00 & 1.00 & 6.01 & 5.44 & 5.94 & 6.97 & 8.57 \\
& 0.33 & 0.67 & 5.95 & 5.69 & 6.22 & 7.07 & 8.26 \\
& 0.50 & 0.50 & 5.90 & 5.80 & 6.35 & 7.10 & 8.05 \\
& 0.66 & 0.34 & 5.84 & 5.88 & 6.45 & 7.10 & 7.81 \\
& 1.00 & 0.00 & 5.67 & 6.00 & 6.63 & 7.07 & 7.18 \\
\hline
\end{tabular}




\section{Table 4}

Impact of volatility on the value (\$ millions) to a risk-averse executive of a portfolio including restricted stock and stock options

Panel B: Constant relative risk aversion of two (CRRA = 2)

\begin{tabular}{|c|c|c|c|c|c|c|c|}
\hline $\begin{array}{c}\text { Portfolio \% in } \\
\text { stock and } \\
\text { options }\end{array}$ & $\begin{array}{c}\text { Restricted stock } \\
\% \\
\end{array}$ & $\begin{array}{c}\text { Stock option } \\
\% \\
\end{array}$ & 0.10 & 0.30 & $\begin{array}{l}\text { S..D. } \\
0.50 \\
\end{array}$ & 0.70 & 0.90 \\
\hline \multirow[t]{5}{*}{$33 \%$} & 0.00 & 1.00 & 5.48 & 5.11 & 5.13 & 5.29 & 5.51 \\
\hline & 0.33 & 0.67 & 5.46 & 5.22 & 5.26 & 5.37 & 5.52 \\
\hline & 0.50 & 0.50 & 5.43 & 5.28 & 5.32 & 5.40 & 5.51 \\
\hline & 0.66 & 0.34 & 5.41 & 5.32 & 5.37 & 5.43 & 5.49 \\
\hline & 1.00 & 0.00 & 5.33 & 5.40 & 5.48 & 5.48 & 5.42 \\
\hline \multirow[t]{5}{*}{$50 \%$} & 0.00 & 1.00 & 5.44 & 4.47 & 4.32 & 4.35 & 4.45 \\
\hline & 0.33 & 0.67 & 5.49 & 4.74 & 4.55 & 4.51 & 4.54 \\
\hline & 0.50 & 0.50 & 5.49 & 4.86 & 4.65 & 4.58 & 4.58 \\
\hline & 0.66 & 0.34 & 5.49 & 4.96 & 4.75 & 4.64 & 4.60 \\
\hline & 1.00 & 0.00 & 5.43 & 5.16 & 4.93 & 4.75 & 4.61 \\
\hline \multirow[t]{5}{*}{$66 \%$} & 0.00 & 1.00 & 5.17 & 3.55 & 3.27 & 3.21 & 3.23 \\
\hline & 0.33 & 0.67 & 5.39 & 4.00 & 3.60 & 3.44 & 3.39 \\
\hline & 0.50 & 0.50 & 5.45 & 4.20 & 3.75 & 3.54 & 3.45 \\
\hline & 0.66 & 0.34 & 5.49 & 4.37 & 3.87 & 3.62 & 3.49 \\
\hline & 1.00 & 0.00 & 5.48 & 4.69 & 4.11 & 3.77 & 3.56 \\
\hline
\end{tabular}




\section{Table 4}

\section{Impact of volatility on the value (\$ millions) to a risk-averse executive of a portfolio including restricted stock and stock options Panel C: Constant relative risk aversion of three (CRRA = 3)}

\begin{tabular}{|c|c|c|c|c|c|c|c|}
\hline $\begin{array}{l}\text { Portfolio \% in } \\
\text { stock and } \\
\text { options }\end{array}$ & $\begin{array}{c}\text { Restricted stock } \\
\%\end{array}$ & $\begin{array}{c}\text { Stock option } \\
\%\end{array}$ & 0.10 & 0.30 & $\begin{array}{l}\text { S.D. } \\
0.50\end{array}$ & 0.70 & 0.90 \\
\hline \multirow[t]{5}{*}{$33 \%$} & 0.00 & 1.00 & 5.29 & 4.66 & 4.54 & 4.54 & 4.58 \\
\hline & 0.33 & 0.67 & 5.32 & 4.82 & 4.68 & 4.63 & 4.63 \\
\hline & 0.50 & 0.50 & 5.32 & 4.89 & 4.74 & 4.68 & 4.66 \\
\hline & 0.66 & 0.34 & 5.32 & 4.96 & 4.80 & 4.72 & 4.67 \\
\hline & 1.00 & 0.00 & 5.28 & 5.09 & 4.92 & 4.79 & 4.69 \\
\hline \multirow[t]{5}{*}{$50 \%$} & 0.00 & 1.00 & 5.01 & 3.82 & 3.60 & 3.54 & 3.53 \\
\hline & 0.33 & 0.67 & 5.19 & 4.12 & 3.82 & 3.69 & 3.63 \\
\hline & 0.50 & 0.50 & 5.25 & 4.26 & 3.91 & 3.76 & 3.68 \\
\hline & 0.66 & 0.34 & 5.30 & 4.38 & 4.00 & 3.81 & 3.71 \\
\hline & 1.00 & 0.00 & 5.32 & 4.62 & 4.16 & 3.92 & 3.77 \\
\hline \multirow[t]{5}{*}{$66 \%$} & 0.00 & 1.00 & 4.41 & 2.80 & 2.57 & 2.49 & 2.45 \\
\hline & 0.33 & 0.67 & 4.88 & 3.23 & 2.83 & 2.67 & 2.58 \\
\hline & 0.50 & 0.50 & 5.04 & 3.43 & 2.94 & 2.74 & 2.63 \\
\hline & 0.66 & 0.34 & 5.16 & 3.59 & 3.04 & 2.80 & 2.67 \\
\hline & 1.00 & 0.00 & 5.31 & 3.90 & 3.20 & 2.90 & 2.74 \\
\hline
\end{tabular}

Note: This table reports the value to a risk-averse executive (constant relative risk aversion of one, two and three for Panels A, B and C respectively) of various combinations of the risk free asset and restricted stock and stock options issued by the firm and given different levels of underlying asset volatility. It is assumed that the executive has an initial portfolio to the value of $\$ 5$ million in risk free assets. The firm leverage is $33 \%$. The composition of the portfolio is then altered without changing the total market value (Black Scholes value) of the portfolio. Essentially a package of restricted stock and stock options valued at market replaces existing investment in the risk free assets such that the package accounts for either $33 \%$, $50 \%$ or $66 \%$ of the total portfolio value. The stock option and restricted stock package is then split between restricted stock and stock options in the proportions $100 \%$ and $0 \%, 67 \%$ and $33 \%, 50 \%$ and $50 \%, 34 \%$ and $66 \%$ and $0 \%$ and $100 \%$. The size of the stock and option package appears in the first column of the table while the percentage of stock options in the package appears in the next column. (The percentage of restricted stock is simply one minus the percentage of stock options in the package.) The last five columns include the risk-averse executive value attached to the portfolio for five levels of standard deviation (S.D.), (10\%, 30\%, 50\%, 70\%, 90\%). 


\section{Figure 1}

\section{Value to an executive of a small grant of restricted stock or stock options}

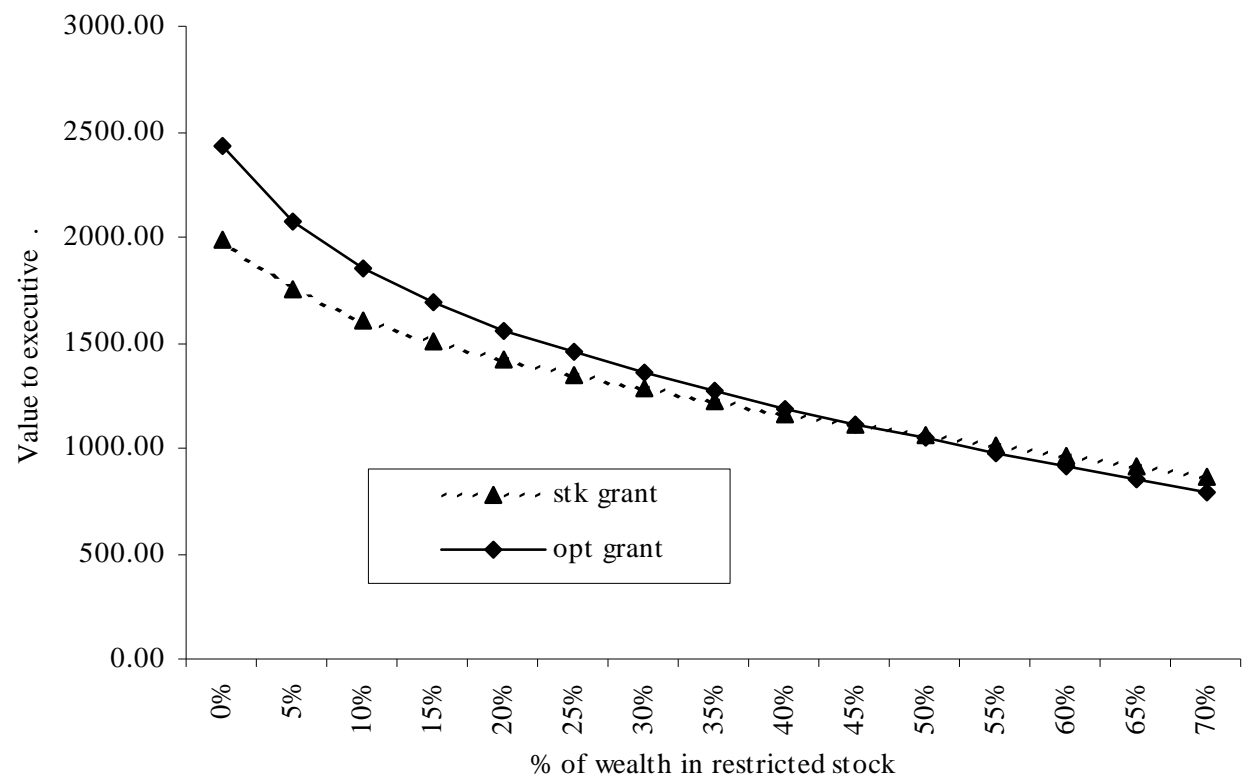

Note: stk grant is the value that a risk-averse executive (constant relative risk aversion of one) places on a grant of $\$ 1000.00$ in restricted stock. opt grant is the value that a risk-averse executive (costant relative risk aversion of one) places on a grant of \$1000.00 in stock options. The number of securities in the grant is determined using the Black Scholes value of the securities and these securities are then valued in the hands of the executive using the adjusted Lambert, Larcker and Verrecchia (1991) model. Leverage is set at 33\% of the underlying asset value and percentage of wealth invested in the stock of the firm varies from $0 \%$ to $70 \%$. 
Figure 2

\section{Value to the executive of a grant of stock options}

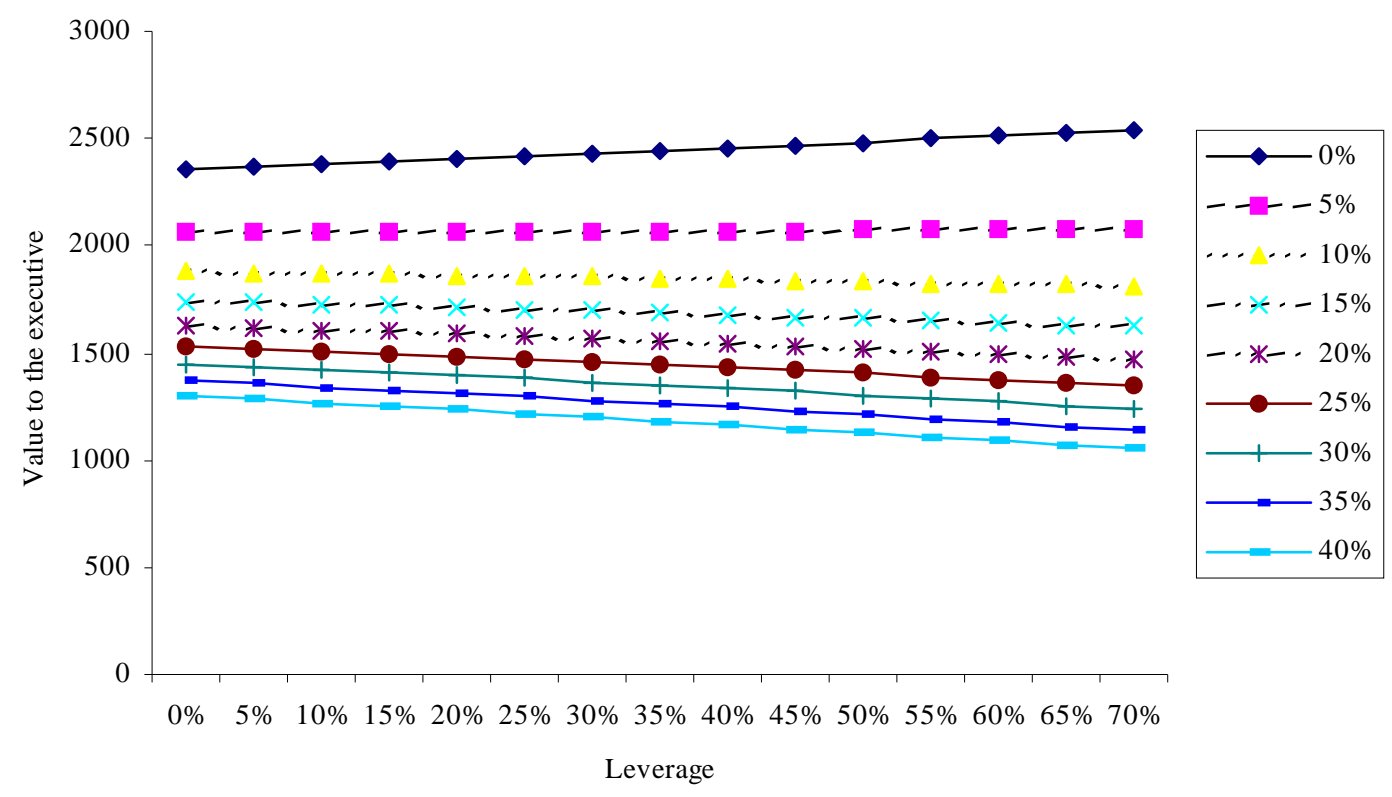

Note: Each line represents the change in value to an executive of a grant of $\$ 1,000$ in stock options as leverage changes given the initial percentage of executive wealth held as restricted stock. The level of relative risk aversion is set at one in this figure. The existing level of restricted stock held by the executive ranges from zero to $40 \%$ of total executive wealth. Leverage is allowed to vary from zero to $70 \%$ of the value of assets in the firm. 


\section{Figure 3}

\section{Impact of leverage on the value an executive places on their investment portfolio (Relative risk aversion of one and 33\% investment in restricted stock and stock options)}

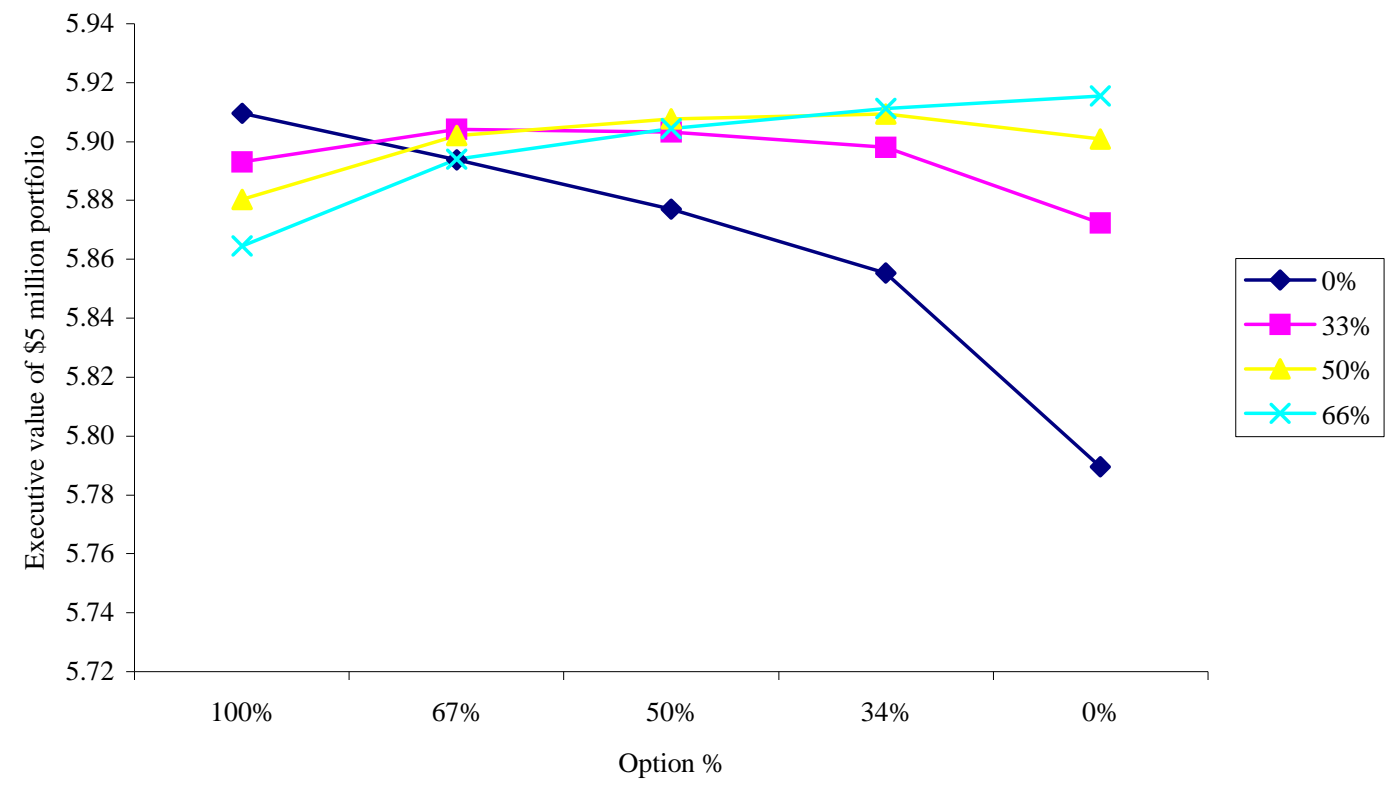

Note: Each line represents the change in value to an executive of their investment portfolio given leverage and given that $\$ 1.65$ million out of a total of $\$ 5$ million (33\%) is available for investment in restricted stock and stock options. The level of stock options is decreased from $100 \%$ to $67 \%, 50 \%, 34 \%$ and then to $0 \%$ of the $\$ 1.65$ million. The level of relative risk aversion is set at one in this figure while leverage takes values of $0 \%, 33 \%, 50 \%$ and $66 \%$ respectively. 


\section{Figure 4}

\section{Impact of leverage on the value an executive places on their investment portfolio (Relative risk aversion of three and 33\% investment in restricted stock and stock options)}

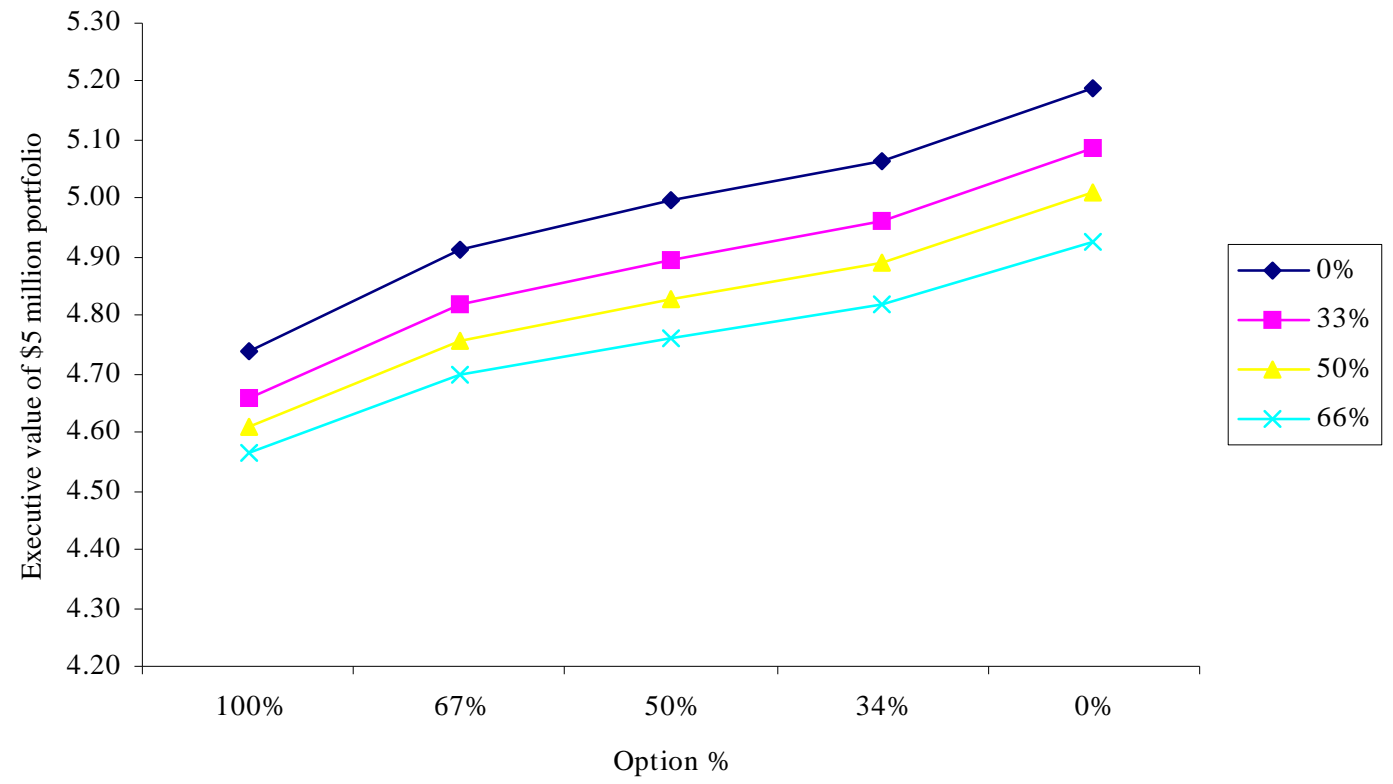

Note: Each line represents the change in value to an executive of their investment portfolio given leverage and given that $\$ 1.65$ million out of a total of $\$ 5$ million (33\%) is available for investment in restricted stock and stock options. The level of stock options is decreased from $100 \%$ to $67 \%, 50 \%, 34 \%$ and then to $0 \%$ of the $\$ 1.65$ million. The level of relative risk aversion is set at three in this figure while leverage takes values of $0 \%, 33 \%, 50 \%$ and $66 \%$ respectively. 


\section{Figure 5}

\section{Impact of volatility on the value an executive places on their investment portfolio (Relative risk aversion of one and 33\% investment in restricted stock and stock options and leverage set at $33 \%$ )}

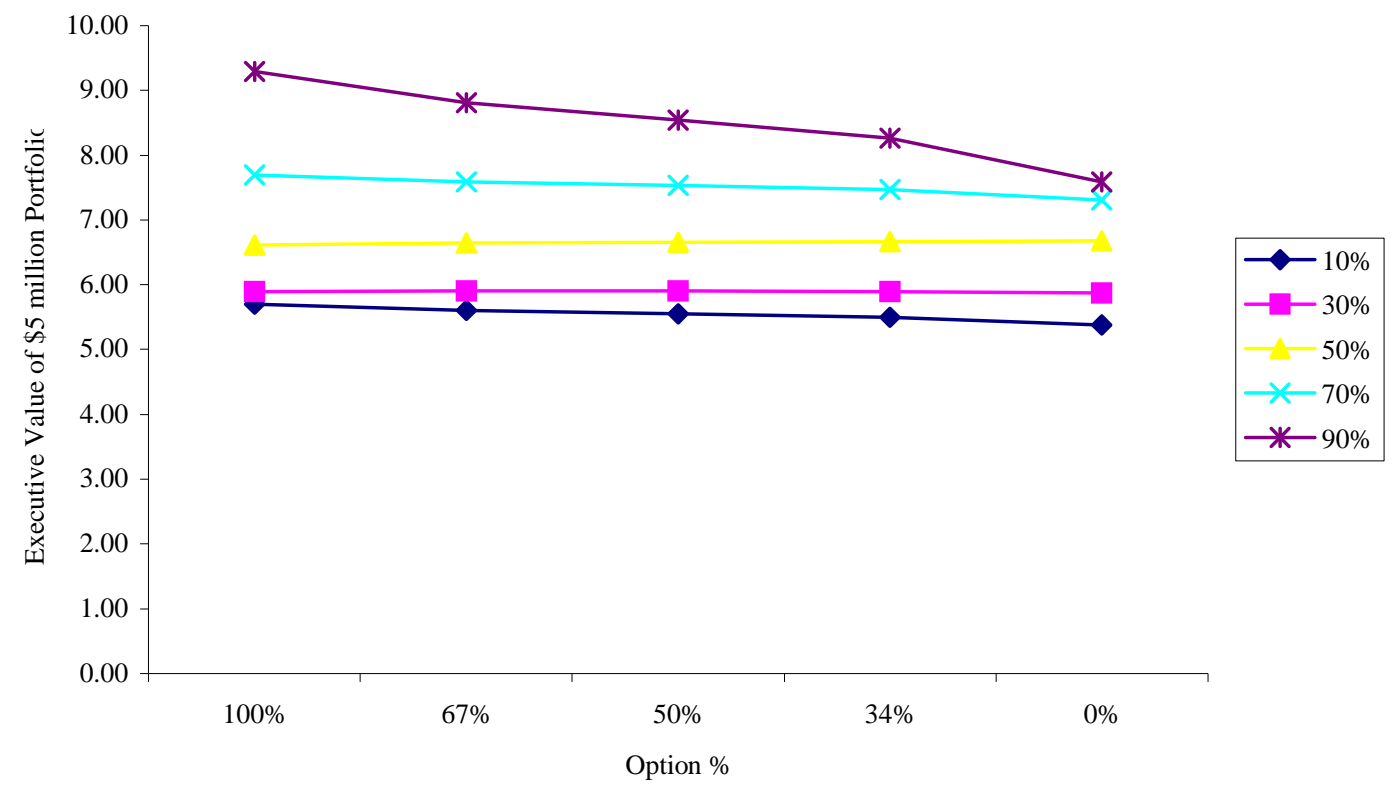

Note: Each line represents the change in value to an executive of their investment portfolio given volatility and given that $\$ 1.65$ million out of a total of $\$ 5$ million (33\%) is available for investment in restricted stock and stock options. The level of stock options is decreased from $100 \%$ to $67 \%, 50 \%, 34 \%$ and then to $0 \%$ of the $\$ 1.65$ million. The level of relative risk aversion is set at one in this figure while leverage takes a value of $33 \%$ and volatility is allowed to vary from $10 \%, 30 \%, 50 \%, 70 \%$ to $90 \%$ respectively. 
Figure 6

\section{Impact of volatility on the value an executive places on their investment portfolio (Relative risk aversion of three and 33\% investment in restricted stock and stock options and leverage set at $33 \%$ )}



Note: Each line represents the change in value to an executive of their investment portfolio given volatility and given that $\$ 1.65$ million out of a total of $\$ 5$ million (33\%) is available for investment in restricted stock and stock options. The level of stock options is decreased from $100 \%$ to $67 \%, 50 \%, 34 \%$ and then to $0 \%$ of the $\$ 1.65$ million. The level of relative risk aversion is set at three in this figure while leverage takes a value of $33 \%$ and volatility is allowed to vary from $10 \%, 30 \%, 50 \%, 70 \%$ to $90 \%$ respectively. 


\section{Footnote}

${ }^{1}$ While Garvey (1997), John and John (1993) and Mehran (1992) include leverage in their analysis, they tend to explore optimal contracting from the point of view of the firm. The executive point of view is the focus of this paper. 